\title{
EUROJUST AND EPPO ON THE CROSSROADS OF THEIR FUTURE COOPERATION ${ }^{*}$
}

\author{
Ante Novokmet, PhD, Assistant Professor \\ Josip Juraj Strossmayer University of Osijek, Faculty of Law Osijek \\ Stjepana Radića 13, Osijek, Croatia \\ ante.novokmet@pravos.hr
}

\author{
Zoran Vinković, LLM, Senior Legal Adviser \\ Municipal State Attorney's Office in Varaždin \\ Kratka 1,Varaždin, Croatia \\ zoran.vinkovic@odovz.dorh.hr
}

\begin{abstract}
On 19 June 2018, the Bulgarian Presidency of the Council, the European Parliament, and the European Commission agreed on the new Eurojust Regulation. The EU ambassadors confirmed the agreement on 20 June 2018 followed by final adoption of the Regulation in November 2018. This paper refers to the novelties introduced by the new Regulation as well as to the projection of relations between agencies after the finalization of OLAF and EPPO competencies. The authors are analysing current modalities for their cooperation on institutional, operational and administrative levels. Will Eurojust become obsolete and possibly a department in the European Public Prosecutor's Office or two differentiated bodies that have a future with separated competencies, independent of each other? What role will OLAF play in relation to both agencies, and what impacts will this have on national criminal justice systems? The authors analyse possible scenarios and point to perceived overlapping in competencies.
\end{abstract}

Keywords: Eurojust, EPPO, mutual cooperation, Regulation (EU) 2017/1939, Regulation (EU) 2018/1727

This paper is a product of work that has been supported by the Croatian Science Foundation under the project 8282 'Croatian Judicial Cooperation in Criminal Matters in the EU and the Region: Heritage of the Past and Challenges of the Future' (CoCoCrim) 


\section{INTRODUCTION}

Since its inception in 2002, ${ }^{1}$ to date, ${ }^{2}$ the European Union Agency for Criminal Justice Cooperation (hereinafter: Eurojust) has moved to an important EU body whose basic task is to improve and coordinate cooperation between judicial bodies of EU member states when these bodies conduct prosecution of criminal acts related to terrorism and organized crime. ${ }^{3}$ In that sense, Eurojust has become an inevitable meeting point for national judicial bodies that coordinates their joint actions and helps solve practical problems arising from everyday practice. ${ }^{4}$ Therefore, it can be pointed out that Eurojust has profiled and positioned itself as an EU body which, on the one hand, ensures a secure exchange of information between EU countries involved in the prosecution of criminal offenses that threaten organized life in the community and on the other hand enhances effective cooperation among them by facilitating the implementation of some instruments of judicial cooperation such as the European Arrest Warrant, joint investigative teams and the seizure and freezing of property. ${ }^{5}$

Eurojust has been intensively building its position as a body responsible for systematically supporting the EU member states in combating various forms of crossborder and organized crime and terrorism for more than fifteen years. ${ }^{6}$ At the same time, the idea for establishing a special EU body responsible for systematic

2002/187/JHA: The Council Decision of 28 February 2002 setting up Eurojust with a view to reinforcing the fight against serious crime. [https://eur-lex.europa.eu/legal-content/GA/TXT/?uri=CELEX:32002D0187] Accessed 15.04.2019

2 This was primarily demonstrated by strengthening the powers of national representatives and the college, strengthening the relationship between Eurojust, the European Judicial Network, and other bodies in the field of judicial cooperation in criminal matters. Council Decision 2009/426/JHA of 16 December 2008 on the strengthening of Eurojust and amending Decision 2002/187/JHA setting up Eurojust with a view to reinforcing the fight against serious crime. [https:/eur-lex.europa.eu/legal-content/EN/TXT/?uri=CELEX\%3A32009D0426] Accessed 15.04.2019

3 See: Suominen, A., The Past, Present and the Future of Eurojust, Maastricht Journal of European and Comparative Law, Vol. 15, No. 2, 2008, pp. 217-234

4 Coninsx points out that Eurojust's most powerful tool is coordination meetings. Coninsx, M., Eurojust, in: Mitsilegas, V.; Bergström, M.; Konstadinides, T., (eds.), Research Handbook on EU Criminal Law, Elgar, 2016, p. 448

5 On problematic issues of the initiation of criminal investigations as well as proposing the initiation of prosecutions and the coordination of investigations and prosecutions according to Art. 85 para 1 subpara 2, (a) and (b) see: Weyembergh, A., Coordination and initiation of investigations and prosecutions through Eurojust, ERA Forum, Vol. 14, No. 2, 2013, pp. 179-185

6 This development was followed intensive cooperation with other EU agencies active in the fight against serious cross-border crime like Europol and the European judicial network. Weyembergh, A., Armada, I., Brière, C., Competition or Cooperation?: State of Play and Future Perspectives on the Relations between Europol, Eurojust and the European Judicial Network, New Journal of European Criminal Law, Vol. 6, No. 2, 2015, pp. 261-283. 
prosecution of criminal offenses committed to the detriment of EU financial interests was also raised on the EU level. ${ }^{7}$ The long-awaited result of the EPPO saga has received its final epilogue on 12 October 2017 with the adoption of the Regulation on enhanced cooperation from $21 \mathrm{EU}$ member states (hereinafter: EPPOReg). ${ }^{8}$ After many years of demanding negotiations, the groundwork and normative framework at the EU-level were created for the effective investigation and prosecution of criminal offenses committed to the detriment of EU financial interests. ${ }^{9}$ The final embodiment of this supranational body of criminal prosecution was greeted with great relief, but at the same time, it has left open a number of institutional questions and procedural concerns that will have to be dealt with on the fly because the first real temptation and answers to serious theoretical and practical issues arise only when the EPPO really starts to live in a conglomerate between national legal orders and decisions that will be made at the European level. ${ }^{10}$ Starting from the good experiences that Eurojust has had in its cooperation with the national judicial bodies so far, the question of its relationship with the EPPO and future cooperation with regard to a certain set of criminal offenses to which it will be responsible can rightly be raised. ${ }^{11}$ This issue became particularly important when the European Parliament, wisely awaiting the completion of the EPPO procedure, adopted a new Eurojust Regulation aiming to prescribe the powers and tasks of Eurojust in the context of its cooperation with the EPPO. ${ }^{12}$

7 The first idea of establishing the EPPO saw the light of day in the 1997 Corpus Juris, which resulted in a mini criminal code for the protection of the Community's financial interests, and then in the 2001 Green Paper on criminal law protection of the financial interests of the community and the establishment of a European Prosecutor. See: M. Delmas-Marty, M.; Vervaele, J.A.E., (eds.), The Implementation of the Corpus Juris in the Member States, Vol. 1, Intersentia, Antwerp-Oxford, 2000

8 Council Regulation (EU) 2017/1939 of 12 October 2017 implementing enhanced cooperation on the establishment of the European Public Prosecutor's Office ('the EPPO'). [https://eur-lex.europa.eu/eli/ reg/2017/1939/oj] Accessed 09.04.2019

9 Following the original proposal of 2013, a series of discussions evolved between the member states, Comission, Council, and the Parliament resulting in numerous amendments. See: Weyembergh, A.; Brière C., Towards a European Public Prosecutor's Office (EPPO), Study for the LIBE Committee, Brussels, 2016

10 Herrnfeld rightly points out that the EPPO would be a new milestone in the development of the areas of freedom, security, and justice, raising new issues of the right balance between the prosecution and defence once when it assumes responsibility for the prosecution of PIF offences. Herrnfeld, H. H., The Draft Regulation on the Establishment of the European Public Prosecutor's Office - Issues of Balance Between the Prosecution and the Defence, in: Weyembergh, A.; Brière, C., (eds.), The Needed Balances in EU Criminal Law. Past, Present and Future, Hart, 2018, p. 411

11 It must be ensured that there is no duplication in mandates and that the law is clear on who is doing what. Csonka P.; Juszczak, A.; Sason, E., The Establishment of the European Public Prosecutor's Office. The Road from Vision to Reality, EUCRIM, No. 3, 2017, p. 131

12 Regulation (EU) 2018/1727 of the European Parliament and of the Council of 14 November 2018 on the European Union Agency for Criminal Justice Cooperation (Eurojust), and replacing and repealing Council Decision 2002/187/JHA. [http://www.eurojust.europa.eu/doclibrary/Eurojust-framework/ 
Therefore, this paper first examines the procedure for the adoption of the new Eurojust regulation with an emphasis on the consequences for the definite design of the relationship between Eurojust and the EPPO, bearing in mind the simultaneous "double track" procedure of discussion and adoption of EPPO and Eurojust regulations. Then, it analyses the new institutional framework of Eurojust by studying the new provisions of the Eurojust regulation, which opens up space for future cooperation between Eurojust and the EPPO. The central part of the paper critically considers the new relations between the EPPO and Eurojust, taking into account the current provisions of the regulation which regulate the normative framework of their powers and duties, examines the real possibilities of their cooperation, and tries to answer some of the issues that arise in the European and national context due to the potential overlapping of their competencies.

\section{NEW EUROJUST REGULATION - LEGISLATIVE PERSPECTIVE}

Along with the proposal of the EPPO regulation, ${ }^{13}$ the European Commission has quite ambitiously presented a new proposal for the Eurojust regulation. ${ }^{14}$ This has introduced a kind of "double track" procedure simultaneously discussing and deciding on the normative regulation of two different EU bodies, which should perform disparate functions but pursue a common goal. ${ }^{15}$ This line of reasoning of the European Commission at first seems to be justified taking into account the role of Eurojust and its primary focus: "to support and strengthen coordination and cooperation between national investigating and prosecuting authorities in relation to serious crime affecting two or more member States or requiring a prosecution on common bases, on the basis of operations conducted and information supplied by the member States' authorities and by Europol" (Art. 85. TFEU). An additional motive for such a procedure was probably found by the Commission in Art. 86 TFEU, which explicitly prescribes: "In order to combat crimes affecting the financial interests of the Union, the Council, by means of regulations adopted

EurojustRegulation/Eurojust\%20Regulation\%20(Regulation\%20(EU)\%202018-1727\%20of\%20 the\%20European\%20Parliament\%20and\%20of\%20the\%20Council)/2018-11-21_Eurojust-Regulation_2018-1727_EN.pdf] Accessed 14.04.2019

13 Proposal for a Council Regulation on the establishment of the European Public Prosecutor's Office, COM (2013) 534 final, [https://eur-lex.europa.eu/legal-content/EN/ALL/?uri=COM:2013:0534:FIN] Accessed 14.04.2019. Proposal for a Regulation of the European Parliament and of the Council on the European Union Agency for Criminal Justice Cooperation (Eurojust) COM (2013) 535, [https://eur-lex.europa.eu/procedure/EN/2013_256] Accessed 18.04.2019

14 Luchtmann, M.; Vervaele, J., European Agencies for Criminal Justice and Shared Enforcement (Eurojust and the European Public Prosecutor's Office), Utrecht Law Review, Vol. 10, No. 5, 2014, pp. 134-135

15 In this regard see: Monar, J., Eurojust's present and future role at the frontline of European Union criminal justice cooperation, ERA Forum, Vol. 14, No. 2, 2013, pp. 198-199 
in accordance with a special legislative procedure, may establish a European Public Prosecutor's Office from Eurojust." ${ }^{16}$ In addition, one of the key objectives of such a parallel reform was to ensure that Eurojust can cooperate closely with the EPPO upon its establishment. Here, the notion "cooperate" should be understood as the intention of the Commission to avoid any overlapping in jurisdiction between the EPPO and Eurojust since it is expressly provided for in the Regulation that Eurojust will not carry out his competences for those crimes under the jurisdiction of the EPPO. This, on the other hand, means that the Commission has conceived the role of Eurojust as a service that will supply the EPPO with all the necessary information and data that EPPO is going to need in order to successfully conduct investigations under his jurisdiction.

Interestingly, such a proposal from the Commission has not undergone significant changes during the debate in the Council. Moreover, the outcome of the negotiations was such that on 13 March 2015, the Council established a kind of general approach to the Eurojust regulation excluding its future relationship between Eurojust and EPPO.${ }^{17}$ The underlying reason for this was the fact that the EPPO debate had not advanced to the extent that the Council could make concrete conclusions regarding the future relations between the two bodies. Such a state of affairs merely confirms that the Commission's plan on the parallel double track system of discussion was rather ambitious. Namely, since both regulations address the same issues, i.e., the forms of future cooperation between such important bodies, it is clear that any delay in negotiations regarding the establishment of the EPPO inevitably prolonged the final agreement on the future functioning of Eurojust.

When the Eurojust regulation proposal, with such focal and practical difficulties, reached the Parliament, further progress in the negotiations was not possible. Therefore, further negotiations were blocked by the Committee on Civil Liberties, Justice, and Home Affairs (LIBE) until the issue of the future cooperation of Eurojust and EPPO is resolved. It is obvious that the Commission's decision on the double-track procedure for adopting such important regulations led to a certain degree of congestion in the proceedings since the actual institutional setting of the EPPO should have a key role in framing the operational relationship between the EPPO and Eurojust. Taking into account all the above-mentioned, the European Parliament recalled the importance of Eurojust's role in improving the judicial cooperation and coordination of the relevant judicial authorities of the member

16 Spiezia, F., The European Public Prosecutor's Office: How to Implement the Relations with Eurojust, EUCRIM, No. 2, 2018, p. 132

17 See: Mitsilegas, V., EU Criminal Law After Lisbon. Rights, Trust and Transformation of Justice in Europe, Hart, 2016, p. 101 
states and in supporting investigations involving non-EU countries. It called on the Council to clarify the relations between Eurojust and the EPPO as well as, in particular, the implications of the collegiate structure and the EPPO's relation with OLAF in order to differentiate between their respective roles in the protection of the EU's financial interests. ${ }^{18}$

Consequently, further debates on the establishment of the EPPO lasted for the next two years before final completion when, on 5 November 2017, the European Parliament ultimately adopted a regulation implementing enhanced cooperation on the establishment of the EPPO. ${ }^{19}$ This new momentum in the development of the EPPO has unblocked the Eurojust file in the Parliament with the LIBE Committee adopting a draft report on 19 October 2017 amending the original proposal of the Commission, which, among other things, discusses the future relations between the EPPO and Eurojust. ${ }^{20}$ Basically, it has been decided that Eurojust will be responsible for the criminal offenses prescribed in the Annex 1 to the Regulation except for those criminal offenses that will be solely the responsibility of EPPO within the framework of enhanced cooperation between member states. At the same time, it was decided that the practical issues of their cooperation would be governed by a working arrangement between them. The decision making process between the Commission, Council, and Parliament on the new Eurojust regulation was finally completed by reaching an agreement on 10 July 2018 and formally adopted on 14 November 2018. The new Eurojust regulation came into force in December 2018, but the application was postponed for a period of one year to allow Eurojust and member states to prepare for the successful implementation of the new rules. ${ }^{21}$

18 European Parliament resolution of 5 October 2016 on the European Public Prosecutor's Office and Eurojust (2016/2750(RSP)), [http://www.europarl.europa.eu/doceo/document/TA-8-2016-0376_ EN.html?redirect] Accessed 15.04.2019

19 On 8 June 2017, 20 EU member states reached a political agreement on the establishment of EPPO under enhanced cooperation. On 1 and 7 August 2018, the Commission gave its approval for the Netherlands (Commission Decision (EU) 2018/1094 of 1 August 2018) and Malta (Commission Decision (EU) 2018/1103 of 7 August 2018) to join the EPPO Regulation, so up to date 22 member states are involved in EPPO enhanced cooperation. Denmark, Hungary, Ireland, Poland, Sweden, and the United Kingdom do not participate in the EPPO

20 On future relations of the EPPO and EUROJUST see: De Amicis, G.; Kostoris, R.E., Vertical Cooperation, in: Kostoris, R.E., (ed.), Handbook of European Criminal Procedure, Springer, 2018, p. 244

21 The regulation entered into force on the twentieth day following that of its publication in the Official Journal of the European Union and shall apply from 12 December 2019 (Art. 82 Regulation) 


\section{RELATIONSHIP BETWEEN EUROJUST AND THE EPPO ACCORDING TO THE NEW REGULATIONS}

Talking about future relations between EPPO and Eurojust is not an easy task. One reason is the very demanding provision of Art. 86 TFEU from which it derives that the "EPPO should be established from Eurojust". ${ }^{22}$ Despite strong connotations transmitted to the outside, this provision has not been prominent in the true sense of the word. Thus, Spiezia points out that "the formula 'from Eurojust' marked one of the most delicate points for the European legislator and for everyone who tries to construe the treaty." ${ }^{23}$ Weyembergh and Brière emphasize that "the exact meaning of such expression is far from clear and its concretisation has been extensively debated, concluding at the same time that regardless of the outcome of the debate, two entities will have a privileged partnership." ${ }^{24}$ On the other hand, the current texts of both regulations emphasize administrative, managerial, and operational links between the EPPO and Eurojust. ${ }^{25}$ Therefore, it should be noted that the relationship between the EPPO and Eurojust should not be viewed from the substantial but rather from the operational level observing the picture of mutual relations in future everyday work that will require good communication and cooperation regarding issues that will be appearing on a daily basis.

This, above all, operational way of cooperation between the EPPO and Eurojust is visible from the EPPOReg text, which explicitly emphasizes that the relationship between the EPPO and Eurojust should be founded on a close relationship between them based on mutual cooperation (Recital 10). Furthermore, guided by the principle of sincere cooperation, Eurojust should actively support the investigations and prosecutions of the EPPO as well as cooperate with it from the moment a suspected offense is reported to the EPPO until the moment it determines whether to prosecute or otherwise dispose of the case (Recital 69). Therefore, it could be argued that the practical relationship between the EPPO and Eurojust should be based on concrete operational issues within their competencies. It means that the EPPO and Eurojust should develop a partnership that will include active cooperation in the areas of their jurisdiction. This will typically involve the

22 See further: Ruggieri, F., Eurojust and the European Public Prosecutor's Office After the Lisbon Treaty, in: Ruggeri, S., (ed.), Transnational Inquiries and the Protection of Fundamental Rights in Criminal Proceedings, Springer, 2013, pp. 223-225

23 Spiezia, op. cit., note 16, p. 133

24 Weyembergh, A.; Brière, C., Relations Between the EPPO and Eurojust—Still a Privileged Partnership?, in: Geelhoed, W.; Erkelens, L.H.; Meij, A.W.H., (eds.), Shifting Perspectives on the European Public Prosecutor's Office, Springer, 2018, pp. 172-173

25 See: Espina Ramos, J.A., The Relationship Between Eurojust and the European Public Prosecutor's Office, in: Bachmaier Winter, L., (ed.), The European Public Prosecutor's Office. The Challenges Ahead, Springer, 2018, pp. 92-95 
investigations conducted by the EPPO wherein an exchange of information or coordination of investigative measures in respect of cases within the competence of Eurojust is considered to be necessary or appropriate (Recital 102).

The aforementioned guidelines interpreted in EPPOReg received the confirmation in the recently adopted EurojustReg. In this respect, it is important to point out that Art. 50 (1) EurojustReg explicitly envisages the establishment and maintenance of close relationships with the EPPO based on mutual cooperation within their respective mandates and competences and on the development of operational, administrative, and management links between them. This provision has been supplemented by the requirement that Eurojust, in its operational procedure which is relevant to the EPPO, shall inform the EPPO of and, where appropriate, associate it with its activities concerning cross-border cases, including the following: (a) sharing information on its cases, including personal data, in accordance with the relevant provisions in this regulation; (b) requesting the EPPO to provide support (Art. 50(4)). Finally, the EPPO may rely on the support and resources of the administration of Eurojust. To that end, Eurojust may provide services of common interest to the EPPO (Art. 50(6)). Since the regulation expressly states criminal offenses ${ }^{26}$ for which Eurojust is competent, a potential overlap in competences between the EPPO and Eurojust may arise. In order to address this problem already in the inception, EurojustReg explicitly stipulates that Eurojust will not exercise its competence in relation to criminal offenses for which the EPPO will undertake investigative and prosecutorial tasks and measures (Art. 3 (1)). ${ }^{27}$

Taking into consideration the presented ideas of cooperation between the EPPO and Eurojust, we should agree with Spiezia that their relationship can be seen in the operational-functional sense. ${ }^{28}$ Although their mutual relations will be explicitly determined by the conclusion of a special working agreement, it should be emphasized that their future relationship should be viewed through the prism of their concordant activities in the context of achieving a common goal, i.e., the effective prosecution of perpetrators of criminal offences within their respective mandates. This can only be achieved if the starting points of their cooperation are mutual respect, assistance and cooperation, whether it is about the exchange of information, facilitating the EPPO's requests for judicial cooperation, or joint participation in judicial cooperation instruments. ${ }^{29}$

\footnotetext{
26 See Annex 1 of the Eurojust Regulation

27 Eurojust will act only exceptionally if member states which do not participate in enhanced cooperation on the establishment of the EPPO are also involved and at the request of those member states or at the request of the EPPO (Art. 3(1))

28 Spiezia, op. cit., note 16 , p. 134

$29 \quad$ Ibid., p. 135
} 


\section{NEW AND IMPROVED EUROJUST UNDER THE INFLUENCE OF THE EPPO}

\subsection{Relationship of trust as a basis of cooperation}

In order to understand the relationship between Eurojust and the EPPO, as envisaged by the new regulations, it is necessary to analyze both legal documents simultaneously. It is already clear from the introductory recitals of the regulations that the cooperation between Eurojust and the EPPO is described in both of them in the context of the competences of the agency to which the regulation relates. This is probably the result of the "double track" methodology in which regulations were made. It is generally stipulated that the European Public Prosecutor's Office should work closely with other institutions, bodies, offices, and agencies of the Union in order to facilitate the performance of its functions. ${ }^{30}$ Specifically, it describes the cooperation of the two bodies and emphasizes mutual cooperation and respect. ${ }^{31}$ Except for this general provision stated in the EPPOReg, and because of the importance of its work, in EurojustReg, it is stated that the EPPO should become a partner with Eurojust, particularly with regard to operational issues pertaining to their competencies. ${ }^{32}$ What the EPPO Regulation calls "a partnership", the Eurojust Regulation calls "close relationship" between the two bodies. ${ }^{33}$ This can be perceived as an additional guarantee that their cooperation will be at the expected level. The equivalence of their functions, taking into account the diversity of the mandate of each body, is reflected in the fact that the request for a meeting can be equally granted by the President of Eurojust and the European Chief Prosecutor. It is expected that the representatives of the two bodies will have to meet regularly to discuss and deal with questions of common interest. ${ }^{34}$ Eurojust has so far shown itself to be a very useful partner in facilitating communication, real-time contacts, and coordination of judicial bodies of member states. Therefore, it is to be expected that this kind of cooperation from Eurojust will also be required in relation to the EPPO. Especially at the beginning of its mandate, the EPPO will have to use those benefits in terms of operational issues from Eurojust, ${ }^{35}$ taking into account the experience and practice of Eurojust as well as the cooperation and trust that this agency has achieved with EU member states and partner countries.

\footnotetext{
$30 \quad$ For further reference see EPPOReg, Recital 100

31 Marletta A., Inter-institutional relationship of European bodies in the fight against crimes affecting the EU financial interests, EUCRIM, No. 3, 2016, p. 142

32 For further reference see EurojustReg, Recital 102

33 For further reference see EurojustReg Art. 50 (1)

34 Spiezia, op. cit., note 16, p. 132

35 Operational functions of Eurojust are set out under the Art. 4 of the EurojustReg
} 
The trust between two bodies operating in the area of so-called enhanced cooperation should, at the very beginning, be at the level that goes beyond the originalgiven the bodies of the European Union-but it should certainly not be forgotten that the EPPO, in its mandate and responsibilities, is significantly different from Eurojust's. As has been established earlier ${ }^{36}$ and confirmed by the EurojustReg, national representatives in Eurojust act in specific cases primarily on the basis of their national legislation, which allows them to do so and have no vertical responsibility towards the President of Eurojust in the sense of failing to comply with something that is inconsistent with national legislation. On the other hand, the EPPO is independent in its work, and after accepting the function, it is no longer vertically responsible towards the member state government. Therefore, a concrete definition of their relationship is expected in the forthcoming period. Particularly, an answer on how their cooperation will be idyllic in the situations where specific interests of an involved member state will be addressed through a specific subject. It is already noted in the work of Eurojust that national representatives, if they deal with the matter of national interest for the country they are coming from, will not act on the request of another member state if it is in conflict with the interests of their native state.

\subsection{Certain aspects of the future interaction of Eurojust and the EPPO}

In the regulation, Eurojust's competences are now clearly set out, ${ }^{37}$ and the forms of serious crime for which Eurojust is competent are now listed in an Annex 1 of the regulation. ${ }^{38}$ The EurojustReg also defines the categories of related offences for which Eurojust is competent. It also outlines that, in general, Eurojust shall not exercise its competence with regard to crimes for which the EPPO is competent. The practical details of Eurojust's exercise of competence, however, shall be governed by an additional working arrangement. ${ }^{39}$ Ultimately, when requested by a competent authority of a member state, Eurojust may also assist with investigations and prosecutions for forms of crime other than those in Annex 1. It is true that Eurojust is set up to "combat serious crimes" in order to refer Eurojust's jurisdiction to the criminal nomenclature to more complex criminal offenses, but

36 Weyembergh; Brière, op. cit., note 24, pp. 172-173

37 Without referring to the Convention based on Article K.3 of the Treaty on European Union, on the establishment of a European Police Office (Europol Convention), as it was previously set in the Council Decision 2009/426/JHA of 16 December 2008 on the strengthening of Eurojust and amending Decision 2002/187/JHA setting up Eurojust with a view to reinforcing the fight against serious crime

38 Eurojust regulation Annex 1

39 See also: Deboyser C, European Public Prosecutor's Office and Eurojust: Love Match or Arranged Marriage?, in: Erkelens, L.H.; Meij, A.W.H.,; Pawlik, M., (eds.), The European Public Prosecutor’s Office. An extended Arm or a Two-Headed Dragon, Springer 2014, p. 82 
in reality, this is not the case at all. Therefore, regardless of whether it is necessary to make delivery of some documents, to determine the address of a witness or defendant or to make a decision to freeze a property, it is always possible, without hesitation, to contact Eurojust. ${ }^{40}$

In cross-border cases, the exchange of information is particularly important. In that sense, Eurojust proved to be a very useful mediator in such exchanges through the organization of meetings for that cooperation and contacts between the judicial bodies of the EU member states. ${ }^{41}$ There is no reason for this role of Eurojust not to be realized in relation to the EPPO. Both regulations envisage data exchange through IT systems. In this regard, we believe that it is of great importance to enable joint usage of specific technologies, i.e., through the Case Management System (hereinafter: CMS) already used by Eurojust, which would also contribute to increased trust. Although, it has been set by the regulation ${ }^{42}$ that the CMS of Eurojust will be available to the EPPO, time will show whether it will be in the form of using the same system with additional user data or by linking a CMS with an autonomous system that would only be used by EPPO. ${ }^{43}$ An additional barrier to such data exchange could be that not all EU member states participate in a system of intensified cooperation through the EPPO for which reason it is expected that it will not be willing to share all information from that system. Although the EPPO will take over the organizational dimension to achieve its full operational incentive, it still has room for improving the capacity of Eurojust in accordance with Art. 85 TFEU in particular in the field of the fight against terrorism, where more extensive information exchange is needed. ${ }^{44}$

Judicial cooperation in criminal matters at Eurojust is achieved through the work of national members. A national member may directly contact the competent authorities of his member state. This has been done to ensure full functioning of the work of national members so that they can contact the competent judicial authorities in their respective countries without any delay and to respond to the request of other national members at any time in the appropriate database. Issues concerning a national member and its powers are also regulated by the national legislations in all member states. In the Croatian Act on Judicial Cooperation in

\footnotetext{
40 Eurojust Annual Report for 2018 p. 28, via [http://www.eurojust.europa.eu/doclibrary/corporate/eurojust\%20Annual\%20Reports/Annual\%20Report\%202018/AR2018_EN.pdf] Accessed 05.04.2019

$41 \quad$ Ibid., p 9

$42 \quad$ EPPOReg Art. 100 (3)

43 Deboyser, op. cit., note 39, p. 89

44 See also: Spiezia, op.cit., note 16, p. 134
} 
Criminal Matters with EU Member States (hereinafter: AJCCM) ${ }^{45}$ it is regulated by the provisions of Art. 12. a.-12. d. Presumably, the same operational tactics will be used for the EPPO. When referring to national members, and in particular their tasks and powers, it is obvious that they must have the appropriate support in their "native states". That is why the formation of the National Coordinating System is foreseen in the EurojustReg as stipulated by the provision of Art. $12 \mathrm{f}$. of the AJCCM.

One of the most interesting mechanisms of judicial cooperation established in Eurojust, which proved to be very successful in the application, is its joint investigation team. ${ }^{46}$ It is expected that the national members in Eurojust and the European Public Prosecutor will be members of a joint investigation team. That way, evidence-gathering actions can be carried out at the same time in several countries; for performing these actions, there is no need for standard requirements for international legal aid, and the actions that are being implemented in this way and the results obtained thereby (as a rule) are acceptable as evidence for all those participating states of the joint investigative team. In accordance with the domestic legislation, a national member of the Republic of Croatia is a co-signatory of the Joint Investigation Team Agreement. If this has been discussed and agreed upon during the coordination meeting, the national members of the participating states at Eurojust will organize a coordination center. The Coordination Center ${ }^{47}$ is organized on Eurojust's premises, which are especially equipped for this purpose, primarily with a different type of IT device. National members or other officials at national offices are invited to participate in the work of the coordination center, and representatives of the judicial bodies of the involved countries may also be invited. The Coordination Center is held during "Action Day", when all Coordination Center participants in real-time track what is happening in their countries (arrests, interception of consignments, searches, etc.). Considering the fact that the EPPO will have access to all the benefits of Eurojust, it is expected that all this will greatly facilitate its work-especially since it is expected to deal with complex cases, where it is particularly important to have logistical support during the gathering of evidence. Experience in cooperation on the national level with agencies such as OLAF and Europol that has been developed so far-in which Eurojust has been involved, mainly as a facilitator of communication—should also be imple-

45 Law on Judicial Cooperation in Criminal Matters with the Member States of the European Union, Official Gazette of the Republic of Croatia 91/10, 81/13, 124/13, 26/15, 102/17, 68/18

46 In detail about the nature and legal nature of joint investigative teams see: Rijken, C., Joint Investigation Teams: principles, practice, and problems Lessons learnt from the first efforts to establish a JIT, Utrecht Law Review Vol. 2, No. 2, 2006, pp. 99-118

47 For more about the Eurojust coordination centre, see the following: [http://www.eurojust.europa.eu/ Practitioners/operational/Pages/eurojust-coordination-center.aspx] Accessed 15.04.2019 
mented by the EPPO operational work. OLAF will probably no longer be able to perform all current functions.

This means that when it comes to full alignment with the EPPO and Eurojust, its competence will be changed. For example, instead of carrying out its own administrative investigations alone, it will have to comply with the EPPO before taking such actions. In this way, duplication of treatment or investigation will be avoided. More active involvement of OLAF is also expected in meetings between the EPPO and Eurojust. In order to truly have the functioning of the three bodies, further harmonization of their actions will need to be made through special working agreements and internal acts. ${ }^{48}$

\subsection{Practical Projections of Cooperation between Eurojust and the EPPO}

If a hypothetical situation is set in which the EPPO could seek specific assistance from Eurojust, we would consider it possible for three types of relations to occur when working on the case under its jurisdiction. The first case would refer to the situation in which the EPPO would seek the participation of Eurojust in the case of a member state that is a member of the EPPO. Let's call it a case of complete cooperation. In this case, the preconditions for cooperation will be at the highest level since the EPPO will, through Eurojust and its national members, be able to contact the domestic judiciary of that state and the delegated EPPO prosecutors who will be able to participate in coordination meetings with Eurojust national members and in all the operational permutations that have been introduced in the practice of Eurojust. It is even expected that the European delegated prosecutor could ask the judge to issue a European arrest warrant ${ }^{49}$ to be executed in a state where the intervention of the national member of Eurojust could facilitate or support the enforcement. In the second case, where the EPPO will seek cooperation with the non-EPPO EU member state, there should be no bigger problems, but in this case, a greater involvement of Eurojust, i.e., the activation of mechanisms that nowadays function in the daily work of the agency, is expected. This means cooperation with the EPPO will only be facilitated through national members and the domestic judiciary of non-EPPO member states. It is expected that in this case, the EPPO will have to give more arguments in favour of its requests, i.e., that it will not have additional assistance through the European delegated prosecutors

\footnotetext{
48 In detail see: Proposal for a Council Regulation amending Regulation (EU, Euratom) No 883/2013 concerning investigations conducted by the European Anti-Fraud Office (OLAF) as regards cooperation with the European Public Prosecutor's Office and the effectiveness of OLAF investigations, COM (2018) 338 final, [https://eur-lex.europa.eu/legal-content/EN/TXT/?uri=COM\%3A2018\%3A338\%3AFIN] Accessed 15.04.2019

49 Art. 33 of the EPPOReg
} 
and will cooperate with national judicial officials. The contact points of the European Judicial Network could, in that situation, be a significant source of the additional facilitation of communication with a non-EPPO member state. ${ }^{50}$ In the third alternative, there would be a situation in which the EPPO would seek the assistance of Eurojust in contact with non-EU countries that were partner countries of Eurojust. In these situations, it may be the most useful for the EPPO as it is at this stage still unclear how the requests for international legal aid issued by it will be interpreted by non-EU countries. The relationship between these countries with Eurojust and their steadfast trust in such situations could be of the greatest benefit to obtaining some evidence or providing any other form of international cooperation required by the EPPO.

\section{CONCLUSION}

By prescribing Eurojust and the EPPO in the form of a regulation, the European legislator has shown that both actors are considered to be particularly important for the future development of European criminal law. By confirming Eurojust, which is a continuing success story, and introducing a new European judicial body, it is a unique opportunity for a step ahead towards a concept of federal Europe in the area of criminal justice. Obviously, the simultaneous adoption of both regulations, which contain many links for the various fields concerned, allow them different forms of cooperation and further development of their cooperation in the future. From the perspective of both bodies, it is evident that the vision of the European Commission was obviously to form the EPPO as a completely separate body from Eurojust and to lay the foundations for their coexistence on the European stage. Despite formal separation, apparently knowing that such assistance would be needed, Eurojust was enabled to provide the EPPO functional support in its first years of operation. In addition to economic savings, this will surely contribute to the final redefinition of the division of their tasks, which was not provided in the text of the regulation because there was no suitable template to follow. This support will not undermine the guaranteed independence of the EPPO. It should be considered that many issues pertaining to jurisdiction or modality of action will also finally be defined when the coexistence and cooperation of the two bodies really begins to exist. In this context, the future working agreement of the EPPO with Eurojust must establish criteria that will make it possible to smoothly define the limits of their cooperation.

50 The main role of the EJN Contact Points is to facilitate judicial cooperation in criminal matters between the EU Member States, particularly in actions to combat forms of serious crime, [http://www. eurojust.europa.eu/Practitioners/European-Judicial-Network/Pages/European-Judicial-Network.aspx] Accessed 15.04.2019 


\section{REFERENCES}

\section{BOOKS AND ARTICLES}

1. Coninsx, M., Eurojust, in: Mitsilegas, V.; Bergström, M.; Konstadinides, T., (eds.), Research Handbook on EU Criminal Law, Elgar, 2016, pp. 441-457

2. Csonka P.; Juszczak, A.; Sason, E.; The Establishment of the European Public Prosecutors's Office. The Road from Vision to Reality, EUCRIM, No. 3, 2017, pp. 125-135

3. De Amicis, G.; Kostoris, R.E.; Vertical Cooperation, in: Kostoris, R.E., (ed.), Handbook of European Criminal Procedure, Springer, 2018, pp. 201-249

4. Deboyser C., European Public Prosecutor's Office and Eurojust: Love Match or Arranged Marriage?, in: Erkelens, L.H.; Meij, A.W.H.; Pawlik, M., (eds.), The European Public Prosecutor's Office. An extended Arm or a Two-Headed Dragon, Springer 2014, pp. 79-101

5. Espina Ramos, J.A., The Relationship Between Eurojust and the European Public Prosecutor's Office, in: Bachmaier Winter, L., (ed.), The European Public Prosecutor's Office. The Challenges Ahead, Springer, 2018, pp. 87-103

6. Herrnfeld, H. H., The Draft Regulation on the Establishment of the European Public Prosecutor's Office - Issues of Balance Between the Prosecution and the Defence, in: Weyembergh, A.; Brière, C., (eds.), The Needed Balances in EU Criminal Law. Past, Present and Future, Hart, 2018, pp. 383-413

7. Luchtmann, M.; Vervaele, J., European Agencies for Criminal Justice and Shared Enforcement (Eurojust and the European Public Prosecutor's Office), Utrecht Law Review, Vol. 10, No. 5, 2014, pp. 132-150

8. Marletta A., Inter-institutional relationship of European bodies in the fight against crimes affecting the EU financial interests EUCRIM, No. 3, 2016, pp. 141-144

9. M. Delmas-Marty, M.; Vervaele, J.A.E., (eds.), The Implementation of the Corpus Juris in the Member States, Vol. 1, Intersentia, Antwerp-Oxford, 2000

10. Mitsilegas, V., EU Criminal Law After Lisbon. Rights, Trust and Transformation of Justice in Europe, Hart, 2016

11. Monar, J., Eurojust's present and future role at the frontline of European Union criminal justice cooperation, ERA Forum, Vol. 14, No. 2, 2013, pp. 187-200

12. Rijken, C., Joint Investigation Teams: principles, practice, and problems Lessons learnt from the first efforts to establish a JIT, Utrecht Law Review, Vol. 2, No. 2, 2006, pp. 99-118

13. Ruggieri, F., Eurojust and the European Public Prosecutor's Office After the Lisbon Treaty, in: Ruggeri, S., (ed.), Transnational Inquiries and the Protection of Fundamental Rights in Criminal Proceedings, Springer, 2013, pp. 215-229

14. Spiezia, F., The European Public Prosecutor's Office: How to Implement the Relations with Eurojust, EUCRIM, No. 2, 2018, pp. 130-137

15. Suominen, A., The Past, Present and the Future of Eurojust, Maastricht Journal of European and Comparative Law, Vol. 15, No. 2, 2008, pp. 217-234

16. Weyembergh, A., Coordination and initiation of investigations and prosecutions through Eurojust, ERA Forum, Vol. 14, No. 2, 2013, pp. 177-186 
17. Weyembergh, A.; Armada, I.; Brière, C., Competition or Cooperation?: State of Play and Future Perspectives on the Relations between Europol, Eurojust and the European Judicial Network, New Journal of European Criminal Law, Vol. 6, No. 2, 2015, pp. 258-287

18. Weyembergh, A.; Brière C., Towards a European Public Prosecutor's Office (EPPO), Study for the LIBE Committee, Brussels, 2016

19. Weyembergh, A.; Brière, C., Relations Between the EPPO and Eurojust-Still a Privileged Partnership?, in: Geelhoed, W.; Erkelens, L.H.; Meij, A.W.H., (eds.), Shifting Perspectives on the European Public Prosecutor's Office, Springer, 2018, pp. 171-186

\section{EU LAW}

1. 2002/187/JHA: Council Decision of 28 February 2002 setting up Eurojust with a view to reinforcing the fight against serious crime OJ L 063, 06/03/2002 P. $0001-0013$

2. Council Decision 2009/426/JHA of 16 December 2008 on the strengthening of Eurojust and amending Decision 2002/187/JHA setting up Eurojust with a view to reinforcing the fight against serious crime OJ L 138, 4.6.2009, p. 14-32

3. Proposal for a Council Regulation on the establishment of the European Public Prosecutor's Office, COM (2013) 534 final 2013/0255 (APP)

4. European Parliament resolution of 5 October 2016 on the European Public Prosecutor's Office and Eurojust (2016/2750(RSP)) OJ C 215, 19.6.2018, p. 18-20

5. Council Regulation (EU) 2017/1939 of 12 October 2017 implementing enhanced cooperation on the establishment of the European Public Prosecutor's Office ('the EPPO') OJ L 283, 31.10.2017, p. 1-71

6. Regulation (EU) 2018/1727 of the European Parliament and of the Council of 14 November 2018 on the European Union Agency for Criminal Justice Cooperation (Eurojust), and replacing and repealing Council Decision 2002/187/JHA OJ L 295, 21.11.2018, p. 138-183

7. Proposal for a Council Regulation amending Regulation (EU, Euratom) No 883/2013 concerning investigations conducted by the European Anti-Fraud Office (OLAF) as regards cooperation with the European Public Prosecutor's Office and the effectiveness of OLAF investigations, COM (2018) 338 final

\section{LIST OF NATIONAL REGULATIONS AND ACTS}

Law on Judicial Cooperation in Criminal Matters with the Member States of the European Union, Official Gazette of the Republic of Croatia 91/10, 81/13, 124/13, 26/15, 102/17 and $68 / 18$ 


\section{WEB SITE REFERENCES}

1. [https://eur-lex.europa.eu/legal-content/GA/TXT/?uri=CELEX:32002D0187] Accessed 15.04.2019

2. [https://eur-lex.europa.eu/legal-content/EN/TXT/?uri=CELEX\%3A32009D0426] Accessed 04.04.2019

3. [https://eur-lex.europa.eu/eli/reg/2017/1939/oj] Accessed 15.03.2019

4. [http://www.eurojust.europa.eu/doclibrary/Eurojust-framework/EurojustRegulation/Eurojust $\% 20$ Regulation\%20(Regulation $\% 20(\mathrm{EU}) \% 202018-1727 \% 20$ of\%20the\%20European\%20Parliament $\% 20$ and\%20of\%20the\%20Council)/2018-11-21_Eurojust-Regulation_2018-1727_EN.pdf] Accessed 13.04.2019

5. [https://eur-lex.europa.eu/legal-content/EN/ALL/?uri=COM:2013:0534:FIN] Accessed 15.04.2019

6. [https://eur-lex.europa.eu/procedure/EN/2013_256] Accessed 10.04.2019

7. [http://www.europarl.europa.eu/doceo/document/TA-8-2016-0376_EN.html?redirect] Accessed 09.04.2019

8. [http://www.eurojust.europa.eu/doclibrary/corporate/eurojust\%20Annual\%20Reports/ Annual\%20Report\%202018/AR2018_EN.pdf] Accessed 15.04.2019

9. [http://www.eurojust.europa.eu/Practitioners/operational/Pages/eurojust-coordinationcenter.aspx] Accessed 03.03.2019

10. [http://www.eurojust.europa.eu/Practitioners/European-Judicial-Network/Pages/European-Judicial-Network.aspx] Accessed 15.04.2019 